\title{
A Country in Suspense
}

Political Fallouts and Popular Anxiety

Jérôme Lafargue

\section{(2) OpenEdition}

Journals

Electronic version

URL: https://journals.openedition.org/eastafrica/648

DOI: $10.4000 /$ eastafrica. 648

ISSN: 2790-1076

Publisher

IFRA - Institut Français de Recherche en Afrique

\section{Printed version}

Date of publication: 1 April 2008

Number of pages: 1-10

ISSN: 2071-7245

\section{Electronic reference}

Jérôme Lafargue, "A Country in Suspense", Les Cahiers d'Afrique de l'Est / The East African Review [Online], 38 | 2008, Online since 19 July 2019, connection on 09 December 2021. URL: http:// journals.openedition.org/eastafrica/648; DOI: https://doi.org/10.4000/eastafrica.648

This text was automatically generated on 9 December 2021

Les Cahiers d'Afrique de l'Est / The East African Review 


\title{
A Country in Suspense
}

\author{
Political Fallouts and Popular Anxiety
}

Jérôme Lafargue

1 The widespread violence and turmoil that followed the announcement of the December 2007 presidential election will undoubtedly leave a mark on Kenyan politics for a long time but its effects on the daily lives of millions of people is also very important. Several dynamics are already in motion (social renegotiations within the main ethnic communities, especially concerning relations between the youth and elders; realignment of ties between business environment and the world of politics). More issues are emerging, even though it is still too early to completely assess this (from changes in social representation with regard to political matters, to ethnicity). There are several unknowns, especially because the negotiations for the appointment of a reconciliation cabinet have been protracted. The positions are coveted, not only because of possibilities of a ministerial position but also in view of future presidential elections. Five years, is after all a very short period in politics. ${ }^{1}$

2 Although the negotiations conducted by Kofi Annan for more than a month concluded on 28 February 2008 with a power-sharing agreement in principle, ${ }^{2}$ a lot remains to be done, beginning with the appointment of coalition partners. Who will R. Odinga's deputy prime ministers be? By the beginning of April 2008, Musalia Mudavadi's was an undisputed name in ODM, but it was not yet obvious who the choice of PNU would bethe jostling between Uhuru Kenyatta, representing KANU, and Martha Karua, a close ally of M. Kibaki, was very tough. Nothing had been agreed upon on the sharing of key ministerial positions (e.g. foreign affairs, local government, transport). It was a strange period of suspense in which the power struggle seemed to overshadow the enormous difficulties that the internally displaced persons were experiencing. It was also a strange period with power vacuum, leading the casual observer and citizen alike to wonder when the real challenges facing the country would be settled, beginning with employment and the land embroilment. ${ }^{3}$

3 The subsequent spiralling skirmishes and violence during the months of January and February 2008 displaced hundreds of thousands and led to more than one thousand deaths. An initial assessment of the elections and the violence has been made further in 
this volume ${ }^{4}$. This paper will concentrate on a set of themes that seem essential for both an understanding of the stakes in the conflict and to weigh the medium-term consequences.

4 Hervé Maupeu revisits the violence that occurred across the country. He outlines the various interpretations put forward during the crisis and clearly shows that political and electoral violence can be different in nature. He thus attempts to bring out the elements that help explain why the announcement of the election results was followed by such large-scale unrest. By tracing R. Odinga's political evolution and the consolidation of his tools of control, it becomes clearer that in 2007, the opposition had a better oiled political machine than ever before. The establishment expected a reaction if $\mathrm{M}$. Kibaki was re-elected but it had not imagined the reaction would reach the heights that it did. Hervé Maupeu uses the conflicts in the Rift Valley to illustrate the mechanism of violence from a social and historical perspective. Indeed, the 2007 elections reactivated the sources of tension in this province, some going back to the massacres of the 1990s, and also as far back as the Mau Mau crisis of the 1950s, while some do not directly echo the anti-colonial revolts of the 1920s. Taking Molo, Kuresoi and the Mau Forest as examples, he unravels the motives of the often fragile political strategies as well as the extremely sensitive role of land allocation in the search for stability (or in some cases instability). Finally, Maupeu offers leads in understanding the complex attitude of the police, particularly in urban areas (Kisumu and Nairobi), as they sought to quell the violence.

5 As demonstrated by Ronan Porhel, who begins by discussing the essential role that Kenya plays in the region, there were many economic consequences of the unrests, even though the financial markets strongly withstood the uncertainty. The tourism sector was the most affected by the crisis: cancellation of flights and tours, withdrawal of companies, massive layoffs. Many farms suffered because of destruction through looting, settling of scores or because workers could not access their work places due to roadblocks or lack of road transport. The crisis also simultaneously affected the banking sector and the small enterprises directly engaged in micro-credit systems. Recovery was slow everywhere and regaining the level of activity comparable to 2007, in the tourist, agricultural or the business sector would take several months, or even more than a year.

6 Claire Médard then attempts to explain the crisis from the land dimension. The skirmishes surprised observers by the scale of violence, their intensity and their spontaneous nature. The degeneration into ethnic clashes heightened concern and fear of their spiralling out of control. However, they had not all been politically instigated but the conflict, particularly in the rural areas showed the seriousness of the regional grievances, marked by land expropriation issues, ethnic considerations and land privatization. Claire Médard attempts to untangle the complex web of the multiple ethnic demands, some of which were the underlying causes of violence. By so doing, she aptly demonstrates to what extent the notion of ethnicity can become completely rigid depending on the situation, how it was used by the communities themselves with a view to political assertion and in the hope of regaining grabbed land. Finally, in order to tackle the sole issues which remain important-protecting the rights of the poorest and their access to land, Claire Médard endeavours to establish, backed by examples, the role played by these ethnic-based demands and their role in converting politics into 
a tool. Is a peaceful settlement of the land problem really possible after decades of poor management and land expropriation?

7 However, several institutions seem weak. The political crisis exposed the extent of their shortcomings. Starting with the example of the ECK, Anne Cussac outlines the origins of its numerous shortfalls. She revisits the beginnings the electoral commission and its composition and reveals the social network stakes that permeate Kenyan politics. The failure by the commission to guarantee free and fair elections will leave its mark, not so much on the institution's credibility, which is already at its lowest ebb, but on the understanding of the democratic process itself by citizens. Anne Cussac also pinpoints the merely theoretical independence of the judiciary that has been perverted by political schemes and strategies. Has the death knell sounded for the Kenyan political model in spite of the election of a new parliament? The ODM brought in new faces, most of whom are young, and will perhaps be able to provide a breath of fresh air into Kenyan politics. However, the question that lingers is the institutional framework within which they will evolve.

What can the civil society do under these circumstances, and more importantly, what did it achieve in the events that marked the beginning of the year? Hervé Maupeu dwells lengthily on the stalemate the Christian churches found themselves in. Under the Moi era, the political divisions were clear-cut: the moral side was indisputably in the opposition camp. Hence the most influential churches helped M. Kibaki take over power. Even further, they endorsed his policies, including during the most critical moments such as the 2005 referendum and the 2007 election campaigns. How then, could they, during the post-election unrests, criticize or denounce the same people they had supported for five years? The quest for some neutrality, by calling for consensus between the protagonists, did not seem credible. Christian churches, which were once the backbone of the civil society, need to redefine their role in politics. In contrast, Muslim organizations emerged from the crisis holding their heads high: they showed their capacity to influence the vote of their faithful and knew how to control the gangs of looters who were quick to hijack the various causes under false pretences. Finally, Hervé Maupeu revisits the black spot of unrests and the issue of militias, using the example of the most important and probably the most complex of them all, Mungiki. Without an analysis of this group from a religious perspective, one is likely to miss out an important dimension of its influence, which is not only felt in the political arena but also in the redefinition of the relationship between the youth and the elders, notably within the Kikuyu ethnic community. Understanding the Mungiki movement is a challenge for social studies: people simply want to view it as a gang of youth politically organized to cause mayhem, yet a number of them refused to participate in the excesses perpetrated in January and February 2008, for instance. Above all, the Mungiki religious and revivalist scope should not be overlooked, as it revolves around prophetism and the memory of the Mau Mau, reminiscent of the resistance movement's rituals in the 1950s. The tension between State leadership and the Mungiki is significant- sometimes it is useful, sometimes it is on the 'most wanted' list. The Kibaki regime's treatment of the sect clearly shows the shape that the intra-Kikuyu civil war is taking. There are numerous social barriers within this ethnic group and they prevent accomplishments, especially by the young. The return of the warrior image and the recourse to violence can under these circumstances become the means to success that they cannot access through other means. From a pacifist perspective, where are human rights organizations? The final comment made by Dominique Connan 
is not exactly optimistic. The ability to influence events by this strand of the civil society has not changed over the last ten years. This is more so because its sense of responsible citizenship was whittled down by its relative inertia over the unequal distributions of the gains of economic growth during Kibaki's first term in office. Civil society organizations participated in the 2005 constitutional debate. They mobilized during the election campaigns and were among the first to unite in expressing their indignation and denouncing the manipulation of the polls. However, there were divisions within the civil society. This is demonstrated by the divergence in the interpretation of the crisis, with a split between a group considering peace as an indisputable option through negotiations with the government, and another group, sharply opposed to this position. In contrast, some groups engaged in trying to propose several ways out of the crisis. During this period, other fissures of discord emerged, exposing the disparity in the aspirations of members of the organizations. Splits, cases of reconstitution and continued occupation of office were the order of the day in these organizations, which was evidence that even within this sector, network battles were equally vicious.

9 The last part of this publication focuses on the role played by the media and the pollsters, both during the campaigns and after. Brice Rambaud casts the spotlight on the increasing independence of the mainstream media vis-à-vis the political class, which does not stop it from targeting political links, like economic dependency by some media houses. The emergent media panorama is inspiring, in terms of diversity of the available press and radios. Vernacular radio stations were eager to do anything possible to ethnically slant their material. The press was unrelenting in its focus on election contest, sometimes relegating other topics to the very last pages. The media coverage made it possible to identify the general tendencies such as the micro-stakes at play in the campaigns. The elections were also the subject of significant coverage on television and on the web, with the creation of websites dedicated to the main candidates as well as the creation of blogs by journalists. Brice Rambaud then endeavours to study the manner in which the press reported the post-election violence. He explains the double act of informing and condemning the violence. More generally, he talks about proactive journalism to define the attitude of media professionals towards the events, whilst they had to protect themselves against hawk-eyed government censorship, especially as far as television coverage was concerned. A study of the initial days of the crisis shows the sometimes frustrated willingness of journalists to provide the most informative and objective news information. On her part, Florence Brisset-Foucault, after analyzing the origins of political communication in Kenya, concentrates on television, particularly the talk-shows. She expresses apprehension over professionalism in the talk-shows and emphasizes the moral and political models that are projected and defended at the talk-shows, or which the presenter sometimes misses out. She therefore is in a position to give an overview of the contrasting points of view of the politician, where the ideas of fair and balanced coverage depend on shifty arrangements. She also demonstrates that the broadcasts discouraged personality politics and preferred individuals to the problems they claimed to seek to solve or the causes they sought to stand for. Personal productions have also been described, and it is worth noting that they are either based on the expression of political convictions or ethnic leanings. Finally, Patrick Mutahi presents us with the first overview of the role of opinion polls in politics. Used like never before, these tools were subjected to multiple political interpretations. Of particular significance was the issue of reliability, 
which proved to be sensitive during election campaigns, and rapidly indicated that the race between the two leading candidates would be tight. Mutahi also tackles the ambiguous role sometimes played by pollsters, based on ethnic orientation and political preferences. At the end of the day, while noting that the public had never been properly informed about the methods used by the pollsters, the system is found to be too opaque to be genuinely credible.

Democracy is undoubtedly in its infancy in Kenya. However, despite the traumatic violence that occurred, it is not necessarily built on ruins today. A few strong foundations remain standing and some pillars still seem quite strong, such as freedom of speech or the right to legally oppose. The institutional and governmental ups and downs since March 2008 have been closely followed by voters, but a degree of weariness is now unsurprisingly catching up with them. The disappointment over the scale of electoral fraud, whose proof becomes more evident with the release of various reports, ${ }^{5}$ comes with real mistrust of the political class by citizens and a questioning, which should be taken very seriously, of the usefulness of the ballot. Added to this is the meaning of democracy and the ability of politics to solve the most urgent problems, be they economic or social. ${ }^{6}$ The expectations of citizens in Kenya have risen highly Will the political class be able to promptly respond?

\section{NOTES}

1. Presidential and parliamentary elections were held on 27 December 2007. According to the Electoral Commission of Kenya (ECK), the outgoing President Mwai Kibaki, was re-elected on the ticket of a new coalition called Party of National Unity (PNU, created a few weeks before the polls) with 4,584,721 votes (46\%) against 4,352,903 (44\%) garnered by Raila Odinga, leader of ODM (Orange Democratic Movement, a coalition formed during the 2005 referendum debate) and 879,903 (9\%) garnered by Kalonzo Musyoka (ODM-Kenya). Voter- turnout was estimated at about $69 \%$. In the parliamentary elections, ODM (99 seats) defeated PNU by a wide margin (43 seats), ODM-K (16 seats) and Kenya African National Union (KANU), the former single party (14 seats) thus confirming its decline. At the same time, Kenyans also elected their civic leaders and the results of the civic polls, in which ODM had a comfortable lead, were only announced in January. Indeed, the announcement of the presidential poll results, due to rumours of rigging perpetrated by the incumbent, led to violent riots that were followed by skirmishes in the country, particularly in Western Province, Nyanza Province, Rift Valley Province, some parts of Central Province, as well as Nairobi, in the slum areas of Kibera, Mathare, Kawangware, Korogocho, Dandora, Huruma and Kariobangi. The initial social revolt paved the way for tribal clashes that put longstanding grievances into perspective, especially land allocation. The former UN Secretary-General Kofi Annan, who arrived in Kenya on 22 January, seemed to be the only one able to conduct a mediation process that would bear fruits. However, for an agreement to finally be reached at the end of February, he had to suspend talks 
between ODM and PNU representatives to a peace talks committee and meet R. Odinga and M. Kibaki directly while some donors also applied intense pressure. For more on these events, refer to the special collection on African Politics, referred to in note 4 below.

2. On 18 March, parliament passed the constitutional amendement that created the prime minister's position. See 'Historic moment', Daily Nation, 19 March 2008.

3. The beginning of April is symbolic of the ambivalent atmosphere. A confidential report by the ECK was leaked under unusual circumstances in Mombasa on 9 March by a human rights organisation, Kenyans for Peace with Truth and Justice. The report revealed several irregularities during the vote counting and tallying procedures (The Standard, $1^{\text {st }}$ April 2008). The same day, the police broke up a protest march staged by about hundred members of the civil society (including Wangari Maathai, Nobel peace laureat, and Maina Kiai, chairman of Kenya National Human Rights Commission), denouncing procrastination in the appointment of the new cabinet (The Standard, 2 April 2008).

4. On this subject, refer to the papers by Anne Cussac, 'Kibaki tena? The contested results of an explosively high stakes election'; Jérôme Lafargue and Musambayi Katumanga, 'Kenya in turmoil. Post election violence and precarious pacification'; Claire Médard, 'Elected leaders, militias and prophets. Violence in Mount Elgon, Kenya, 2006-2008'; Bernard Calas, 'From fraud to violence. Mapping political retrogration').

5. European Union Elections Observation Mission, "Preliminary statement : doubts about the credibility of the presidential results hamper Kenya's democratic progress", $1^{\text {st }}$ January 2008; Commonwealth Secretariat, "Kenya general election, 27 December 2007: the report of the Commonwealth Observer Group", January 2008 ; Kenya Elections Domestic Observation Forum, "Preliminary statement and verdict of the 2007 Kenya's general elections", 31 December 2007; East African Community Observer Mission, "Report on the Kenya general elections, December 2007", January 2008; International Crisis Group (ICG), Kenya in Crisis, Africa Report No 137, 21 February 2008; Human Rights Watch, Ballots to Bullets. Organized Political Violence and Kenya's Crisis of Governance, March 2008.

6. It would be interesting to closely examine these themes within political science, philosophy and history, using broad sociological surveys.

\section{AUTHOR}

\section{JÉRÔME LAFARGUE}

The author is the Deputy Director of IFRA-Nairobi and a researcher in political science. 